\title{
Potrzeby społeczne związane z rozwojem społeczeństwa
}

\section{Social needs related to the development of society}

\section{Streszczenie:}

Istotną zasadą związaną z rozwojem społeczeństwa jest zaspokajanie potrzeb społeczeństwa. Potrzeby te mają wpływ na współżycie ludzi w społeczeństwie. W tej koncepcji głównym podmiotem jest jednostka (człowiek) oraz jej potrzeby, a nie państwo.

Celem artykułu jest próba pokazania, że diagnoza potrzeb społeczeństwa przyczynia się do rozwoju społeczeństwa. Zastosowane metody badawcze to przegląd aktualnej literatury przedmiotu oraz analiza własna przy użyciu piramidy potrzeb Maslowa.

Słowa kluczowe: potrzeba społeczna, rozwój społeczny, wyrównanie szans

\begin{abstract}
:
An important principle related to the development of society is to meet the needs of a given society. These needs affect the intercourse between people in the society. In this concept, the main subject is the individual (human) and its needs, not the state. The article presents an attempt to show that diagnosis of society's needs contributes to the development of society. The applied research methods are an overview of the current literature on the subject and own analysis using Maslow's hierarchy of needs.
\end{abstract}

Keywords: social need, social development, equal opportunities 
Anna Pasek - Potrzeby społeczne zwiq̨zane...

\section{Wprowadzenie}

Potrzeby społeczne związane z rozwojem społeczeństwa można by określić za encyklopedią marketingu, że człowiek żyje dla chleba oraz wtedy, gdy tego chleba brakuje. Natomiast gdy chleba jest pod dostatkiem, a żołądek jest pełny, wtedy od razu pojawiają się inne (wyższe) potrzeby. To one dominują organizm człowieka, a nie potrzeby zaspokajania głodu. Z kolei, gdy te potrzeby zostaną zaspokojone, ponownie pojawiają się nowe (jeszcze wyższe) potrzebyํ. Jak łatwo zauważyć, są to głównie ludzkie działania, myśli i emocje. Są one zdominowane przez aktualny stan psychiczny człowieka.

\section{Rozwój społeczny - definicje i mierniki}

Pojęcie rozwoju społecznego nie jest w literaturze przedmiotu jednoznacznie sformułowane. Według OECD trudność w zdefiniowaniu wynika z samej natury zjawiska. Jest ono niewidzialne, niedotykalne oraz z reguły nieuświadamiane i ukryte w codziennych interakcjach. Oznacza to, że trudno je najpierw zdefiniować, a potem adekwatnie zmierzyćz. Natomiast Międzynarodowa Komisja ds. Pokoju i Żywności (ICPF) (ang. International Commission on Peace and Food) uważa, że rozwój społeczny jest procesem zmiany społecznej, a nie tylko zbiorem polityk i programów ustanowionych dla konkretnych rezultatów. W ciągu ostatnich pięciu wieków proces ten nabrał tempa i intensywności, a w ciągu ostatnich pięciu dziesięcioleci doznał znacznego wzrostu i przyśpieszenia ${ }^{3}$.

Można więc przyjąć, iż rozwój społeczny to powiększenie dorobku naukowego i kulturalnego społeczeństwa, tworzenie coraz lepszych warunków życia ludzi oraz doskonalenie form współpracy i współist-

\footnotetext{
${ }^{1}$ Encyklopedia marketingu. Definicje. Zasady. Metody, Warszawa 1998, s. 243.

2 The well-being of nations. The role of human and social capital, Organization for Economic Co- operation and development OECD, Paris 2001.

${ }^{3}$ International Commission on Peace and Food, Uncommon Opportunities: An Agenda for Peace and Equitable Development, UK, 1994, s. 163.
} 
nienia społecznego. Co za tym idzie, poprawa warunków życia ludzi powinna się opierać na wszechstronnym postępie społecznym, powszechności oraz równości dostępu do urządzeń socjalnych ${ }^{4}$. Głos w tej sprawie zajęli również m. in. P. Sztompka ${ }^{5}$, K. Podolski, W. Turnowiecki ${ }^{6}$, A. Zeliaś ${ }^{7}$, A. Szałkowski ${ }^{8}$, M. Nasiłowski ${ }^{9}$, S. Marciniak ${ }^{10}$, H. Cleveland, G. Jacobs ${ }^{11}$.

Nasuwa się jednak pytanie, czy rozwój społeczny można zmierzyć. Jak się okazuje, szukając mierników rozwoju społecznego, można wyróżnić dwa kierunki działania. Pierwszy proponuje skonstruowanie syntetycznego miernika rozwoju społecznego. Zawarta byłaby w nim większość elementów charakteryzujących rozwój społeczny ${ }^{12}$. Pewną propozycję zestawu mierników rozwoju społecznego zawiera opracowanie UNIDO (ang. United Nations Industrial Organisation) ${ }^{13}$. Mierniki te podzielono na dwie grupy ${ }^{14}$ :

- wskaźniki dotyczące efektów procesu rozwoju społecznego, w tym:

- sytuacja demograficzna (np. długość życia),

- sytuacja zdrowotna (np. śmiertelność niemowląt),

- wykształcenie (np. umiejętność pisania);

- wskaźniki dotyczące nakładów na rozwój społeczny, w tym:

- system wyżywienia (np. spożycie białka),

\footnotetext{
${ }^{4}$ K. Podolski, W. Turnowiecki, Polityka społeczna..., op. cit., s. 35.

5 P. Sztompka, Socjologia zmian społecznych, Kraków,2005, s. 23.

${ }^{6}$ K. Podolski, W. Turnowiecki, Polityka społeczna, Gdańsk 2001, s. 29.

${ }^{7}$ A. Zeliaś, Tradycje i obecne zadania statystyki w Polsce, Kraków 2004, s. 64.

${ }^{8}$ A. Szałkowski, Rozwój pracowników. Przesłanki, cele instrumenty, Warszawa 2002, s. 11.

${ }_{9}^{9}$ M. Nasiłowski, System Rynkowy. Podstawy mikro- i makroekonomii, Warszawa 2004, s. 377, s. 378.

10 S. Marciniak (red.), Makro- i mikroekonomia. Podstawowe problemy, Warszawa 2005, s. 359, s. 360.

${ }^{11}$ H. Cleveland, G. Jacobs, The Genetic Code for Social Development, „Human Choice", World Academy of Art \& Science, USA 1999, s. 959-970.

12 K. Podolski, W. Turnowiecki, Polityka społeczna..., op. cit., s. 35.

13 Organizacja Narodów Zjednoczonych do spraw Rozwoju Przemysłowego, powołana w 1966 r., z siedzibą w Wiedniu.

${ }^{14}$ K. Podolski, W. Turnowiecki, Polityka społeczna ..., op. cit., s. 35.
} 
Anna Pasek - Potrzeby społeczne zwiq̨zane...

- system ochrony zdrowia (np. liczba lekarzy, liczba łóżek w szpitalach),

- system oświatowy (np. liczba szkół, liczba uczniów),

- system komunikacji społecznej (np. liczba gazet, telewizorów, telefonów).

Co za tym idzie, głównym celem działań społecznych i gospodarczych podejmowanych na poziomie lokalnym jest przede wszystkim wzrost dobrobytu oraz poprawa poziomu i jakości życia mieszkańców ${ }^{15}$. Dlatego warto monitować rozwój społeczny. W tej materii ważną rolę spełniają porównania międzynarodowe, m. in. UNDP (United Nations Development Programme), czy GUS (Głównego Urzędu Statystycznego). Raporty te spełniają ważną rolę informacyjną, popularyzacyjną, ale także integrują przedstawicieli nauk społecznych w wypracowywaniu wspólnego stanowiska w sprawie najważniejszych kwestii społecznych ${ }^{16}$.

Skutkami ubocznymi rozwoju społecznego są m. in. mechanizmy polityki finansowej (programów inwestycyjnych, programów związanych $\mathrm{z}$ realizacją funkcji socjalnej państwa, programów zbrojeniowych), polityka podatkowa czy proces, który polega na ograniczeniu wydatków na świadczenia społeczne, oświatę, służbę zdrowia. Kolejnym negatywnym przykładem może być zmniejszenie udziału dochodów pracowniczych w dochodzie narodowym na rzecz dochodów z kapitału. Natomiast naturalnym zjawiskiem są napięcia społeczne ${ }^{17}$.

15 J. Bański, K.Ł. Czapiewski, Ekspertyza. Identyfikacja i ocena czynników sukcesu społeczno-gospodarczego na obszarach wiejskich, Warszawa 2008.

16 J. Witkowski, Statystyka - dokąd zmierzamy? Materiały pokonferencyjne: Statystyka społeczna - dokonania - szanse, perspektywy, Główny Urząd Statystyczny, Warszawa 2008.

17 K. Podolski, W. Tarnowiecki, Polityka społeczna ..., op. cit., s. 34, s. 39. 


\section{Teorie rozwoju społecznego}

Rozwój społeczny według filozofii społecznej, historiozofii, socjologii itp. to proces istotnych, koniecznych i nieodwracalnych przemian społecznych. Mają one określony kierunek i podlegają prawom ${ }^{18}$.

Multidyscyplinarność tego pojęcia wynika z faktu, że rozwój społeczny jest przedmiotem systematycznej refleksji od XVIII i XIX wieku. Teorie na przestrzeni lat różniły się tym, w jakich czynnikach upatrywały zasadnicze przyczyny rozwoju społecznego (przemiany świadomości, cechy biologiczne ludzi, przyrodnicze warunki życia, zmiany demograficzne, rozwój sił wytwórczych, konflikty międzygrupowe itp.). Późniejsze koncepcje z XIX wieku to modyfikacje, analizy i krytyka koncepcji klasyków ${ }^{19}$.

Natomiast w ramach społeczeństwa XX wieku zainteresowanie zbudowaniem uniwersalnej teorii rozwoju społecznego wyraźnie zmalało (choć nigdy nie wygasło całkowicie, podtrzymywane przez marksistów, neoheglistów, neoewolucjonistów i innych), ustąpiło badaniu zmian społecznych w konkretnych społeczeństwach albo stałych lub względnie stałych mechanizmów życia społecznego, które są niezależne od takiej lub innej fazy domniemanego rozwoju społecznego. Upadek teorii rozwoju społecznego nie oznacza jednak, że samo pojęcie rozwoju zostało zamrożone, jest ono nadal używane - na ogół w znaczeniu zbliżonym do potocznego ${ }^{20}$.

Na podstawie powyższych założeń historycznych teorie rozwoju społecznego można podzielić na trzy grupy ${ }^{21}$ :

1) Teorie cykliczne, czyli teorie, które mają charakter cykliczny, tzn. społeczeństwa przechodzą przez kolejne fazy w swym rozwoju, a następnie fazy te się powtarzają od początku. Przedstawiciele to: V. Pareto, K. Kelles-Krauz oraz P. Sorokin.

18 Por: A. Giddens, Socjologia, wydanie nowe, Warszawa 2012, s. 102; P. Sztompka, Socjologia zmian społecznych, Kraków 2005, s. 24.

19 Ibidem, s. 24.

20 Wielka Encyklopedia PWN, t.24, Warszawa 2004, s. 10-11.

21 Za: K. Kelles-Krauz, Historia i rewolucja, Warszawa 1983, s. 89-100. 
Anna Pasek - Potrzeby społeczne zwiqzzane...

2) Teorie dychotomiczne, czyli takie, w których społeczeństwa, przechodząc swój rozwój, przeobrażają się od struktur opartych na grupach pierwotnych do struktur mających formę grup wtórnych i złożonych. Teorie rozpropagowali Ch. H. Cooley, E. Durkheim oraz F. Tönnies.

3) Teorie linearne, czyli takie, w których przemiany społeczeństw następują w toku rozwoju historycznego i zmierzają w określonym kierunku. Mają one charakter fazowy. To znaczy rozwój następuje od stadium pierwotnego aż do fazy końcowej. Głównymi przedstawicielami są A. Comte, H. Spencer i K. Marks.

Socjologiczne teorie rozwoju, ogólnie rzecz biorąc, można podzielić na cztery kategorie ${ }^{22}$ :

1) Teorie, które na podstawie analizy rzeczywistości mają doprowadzić do przyzwoitego wyjaśnienia zjawisk społecznych, umożliwiając konstruowanie weryfikowalnych hipotez dalszego przebiegu procesów. Wada tego podejścia polega na tym, że tego typu teorii nie udało się na razie skonstruować.

2) Teorie, które porządkują, organizują poszczególne zjawiska i ustalają między nimi związki przyczynowe. Tego rodzaju konstrukcje są nazywane teoriami średniego zasięgu.

3) Teoria (konstrukcja intelektualna), która opiera się na analizie rzeczywistości, wypowiadając się jednak na temat przyszłego przebiegu procesów społecznych, których parametry w większości są nieznane, a weryfikacja jest możliwa dopiero ex post.

4) Teoria (konstrukcja intelektualna), która jest rozumiana jako program zmian społecznych formułowanych na podstawie apriorycznych założeń, czyli przepowiedni. W tym samym nurcie znajdują się również najbardziej ogólne wizje pożądanych na ogół stanów rzeczy, inaczej mówiąc - utopie społeczne.

22 B. Jałowiecki, Rozwój lokalny, Warszawa 1989, s. 15. 


\section{Pojęcie, rodzaje potrzeb społecznych}

Mówiąc o diagnozowaniu potrzeb społecznych, należy wyróżnić trzy ważne, podstawowe systemy - przyrodniczy, kulturowy i organizacyjny - jako te, które diametralnie różnicują sytuację wyjściową określania potrzeb społecznych ${ }^{23}$.

Dla polityki społecznej ma to takie konsekwencje, że nie można posługiwać się raz na zawsze ustaloną i potwierdzoną wiedzą o stanie ludzkich potrzeb. Za każdym razem, gdy polityka społeczna ma odpowiedzieć na typowe dla nauk politycznych pytanie: „Co robić, by przeprowadzić zmianę w jakiejś dziedzinie życia społecznego?” trzeba tę odpowiedź poprzedzić diagnozą stanu i sposobu zaspokajania potrzeb konkretnego społeczeństwa w określonym momencie historycznym ${ }^{24}$.

Spośród środków działania polityki społecznej trzeba przede wszystkim wyróżnić świadczenia indywidualne, pieniężne i rzeczowe przyznawane poszczególnym osobom. Świadczenia mogą być powszechnie dostępne, a nawet niekiedy korzystanie z nich jest przymusowe (np. szczepienia ochronne), inne zaś reglamentowane wskutek ograniczeń możliwości zaspokajania potrzeb, np. dostęp do kształcenia w szkole wyższej25.

\subsection{Potrzeby społeczne - istota}

Przedmiotem zainteresowania polityki społecznej są potrzeby, ich rodzaje, stan i sposób ich zaspokajania z punktu widzenia jej celu generalnego, jakim jest postęp społeczny ${ }^{26}$.

Potrzeba to odczuwany przez jednostkę stan braku czegoś, co w związku ze strukturą organizmu, indywidualnym doświadczeniem

${ }^{23}$ A. Lisowski, Potrzeby społeczne i ich diagnozowanie, [w:] A. Kurzynowski, (red.), Polityka społeczna, Warszawa 2005, s. 61.

24 Ibidem, s. 41.

25 K. Podolski, W. Turnowiecki, Polityka społeczna..., op. cit., s. 37.

${ }^{26}$ A. Rajkiewicz, J. Supińska, M. Księżpolski (red.), Polityka społeczna. Materiały do studiowania, Warszawa 1996, s. 41. 
Anna Pasek - Potrzeby społeczne zwiqzane...

oraz miejscem jednostki w społeczeństwie jest niezbędne do utrzymania jej przy życiu. Umożliwia jej rozwój, utrzymuje w określonej roli społecznej, pozwala zachować równowagę psychiczną27. Dlatego można wyróżnić potrzeby w sensie ogólnym (ang. need) oraz potrzeby w sensie szczegółowym (ang. want). Te pierwsze (ogólne) definiuje się jako brak czegoś koniecznego do przetrwania lub dobrobytu. Z kolei te drugie - potrzeby w sensie szczegółowym - stanowią konkretną formę konsumpcji wybraną dla zaspokojenia potrzeby w sensie ogólnym 28 .

Warto dodać, że w ekonomii chodzi o brak konkretnej rzeczy, tj. dobra bądź usługi. Dążenie do zaspokajania owych potrzeb stanowi główny cel wszelkiej działalności gospodarczej. Natomiast sam sposób zaspokajania potrzeb jest jedną z głównych cech tzw. ustroju gospodarczego ${ }^{29}$. Ponieważ ludzie mają pragnienia oraz dysponują środkami, stwarzają popyt na produkty przynoszące korzyści, które dadzą im największą możliwą wartość i satysfakcję ${ }^{30}$. Dlatego w ekonomii potrzeby są rozpatrywane głównie w aspekcie uwarunkowań, możliwości gospodarczych, konsekwencji jednostkowej oraz globalnej konsumpcji ${ }^{31}$.

Wobec powyższego warto również wspomnieć o zbliżonym pojęciu, jakim jest „pragnienie”. Jest to forma, jaką przyjmują ludzkie potrzeby kształtowane przez kulturę oraz indywidualną osobowość oraz przez środowisko, w jakim żyje jednostka. Wyrazem pragnienia są akty pod postacią przedmiotów i obiektów, które te potrzeby zaspokajają. Pragnienia poparte siłą nabywczą przekształcają się w popyt ${ }^{32}$.

\footnotetext{
27 A. Lisowski, Potrzeby społeczne i ich diagnozowanie..., op. cit., s. 52- 53.

28 G. Antonides, W. F. van Raaij, Zachowanie konsumenta. Podręcznik akademicki, Warszawa 2001, s.184-185.

29 W. Šmid, BOSS Leksykon, Kraków 2014, s. 405.

30 G. Armstrong, P. Kotler, Marketing..., op. cit., s. 38.

31 Ekonomia od A do Z. Encyklopedia podręczna, Warszawa 2007, s. 369.

32 G. Armstrong, P. Kotler, Marketing. Wprowadzenie, Warszawa 2012, s. 38.
} 
W literaturze opisane są również potrzeby, których nie można zaspokoić - następuje wtedy ich wyciszenie ${ }^{33}$. Takie zjawisko ma miejsce, gdy mamy do czynienia $\mathrm{z}^{34}$ :

- racjonalizacją potrzeby, tj. próbą uzasadnienia i usprawiedliwienia siebie z niepodejmowanych decyzji;

- sublimacją potrzeby (uszlachetnienie) - konsument, nie mogąc zaspokoić odczuwanej potrzeby, zastępuje ją inną, społeczną;

- ucieczką od rzeczywistości w sferę fantazji, marzeń czy wyobraźni;

- tłumieniem potrzeby - próbą wyeliminowania konieczności $\mathrm{w}$ działaniu do osiągnięcia danej potrzeby ${ }^{35}$.

Warto podkreślić, że spełnienie potrzeby nigdy nie daje pełnego zadowolenia. Jedynie na chwilę usuwa się tylko częściowy dyskomfort. Zaraz po zaspokojeniu jednej potrzeby, pojawiają się następne ${ }^{36}$. Co za tym idzie, stan potrzeb oraz sposób ich wyrażania oraz zaspokajania zależą od tego, w jakim środowisku żyje jednostka. Ma to bowiem związek nie tylko z kondycją człowieka jako organizmu biologicznego, ale również z jego miejscem w systemie społecznym, gospodarczym, politycznym i kulturowym. Zatem istotną sprawą jest historyczna zmienność potrzeb ${ }^{37}$.

Stąd w literaturze pojawiają się liczne klasyfikacje potrzeb, m. in. koncepcja potrzeb wg Murray'a, który wyróżnia 27 potrzeb psychicznych ${ }^{38}$ czy hierarchia potrzeb. W artykule przyjęto hierarchię potrzeb

33 Występuje również zjawisko barier w zaspokajaniu potrzeb, np. bariera religijna czy czasowa. Szerzej: L. Rudnicki, Zachowania konsumentów na rynku, Warszawa 2012, s. 37-38.

${ }^{34}$ Szerzej: Ibidem, s. 38-39.

35 Warto zwrócić uwagę, że redukcja napięcia przez wyciszenie potrzeby, może (ale nie musi) leżeć u podstaw zachowań dewiacyjnych tj. agresji, alkoholizmu, narkomanii.

36 Za: L. von Mises, Ludzkie działanie. Traktat o ekonomii, Warszawa 2007, s. 742.

37 B. Kańtoch, B. Szatur-Jaworska, Diagnozowanie ludzkich potrzeb i ich zaspokajanie w polityce społecznej, [w:] A. Rajkiewicz, J. Supińska, M. Księżpolski (red.), Polityka społeczna. Materiały do studiowania, Warszawa 1996, s. 41.

38 Szerzej: H. A. Murray, Explorations in personality, New York 1938. 
Anna Pasek - Potrzeby społeczne zwiqzane...

jako uniwersalne określenie braków. Hierarchia potrzeb to naturalna kolejność potrzeb od potrzeb biologicznych, takich jak nasycenie gło$\mathrm{du}$, ubranie, mieszkanie, poprzez potrzeby wynikające z sytuacji człowieka $\mathrm{w}$ procesie pracy i $\mathrm{w}$ środowisku społecznym aż po potrzeby wynikające z przesłanek psychologicznych każdej jednostki ${ }^{39}$.

Warto w tym miejscu podać przykład piramidy potrzeb Maslow'a (Rysunek 1). Tworzą ją: potrzeby fizjologiczne (głód, pragnienie), potrzeby bezpieczeństwa (pewność i ochrona), potrzeby społeczne (poczucie przynależności), poczucie szacunku i uznania (poczucie własnej wartości, uznania przez innych, posiadany status społeczny), potrzeby samorealizacji (praca nad sobą i osobiste osiągnięcia) ${ }^{40}$.

Rysunek 1. Hierarchia potrzeb według Abrahama H. Maslowa

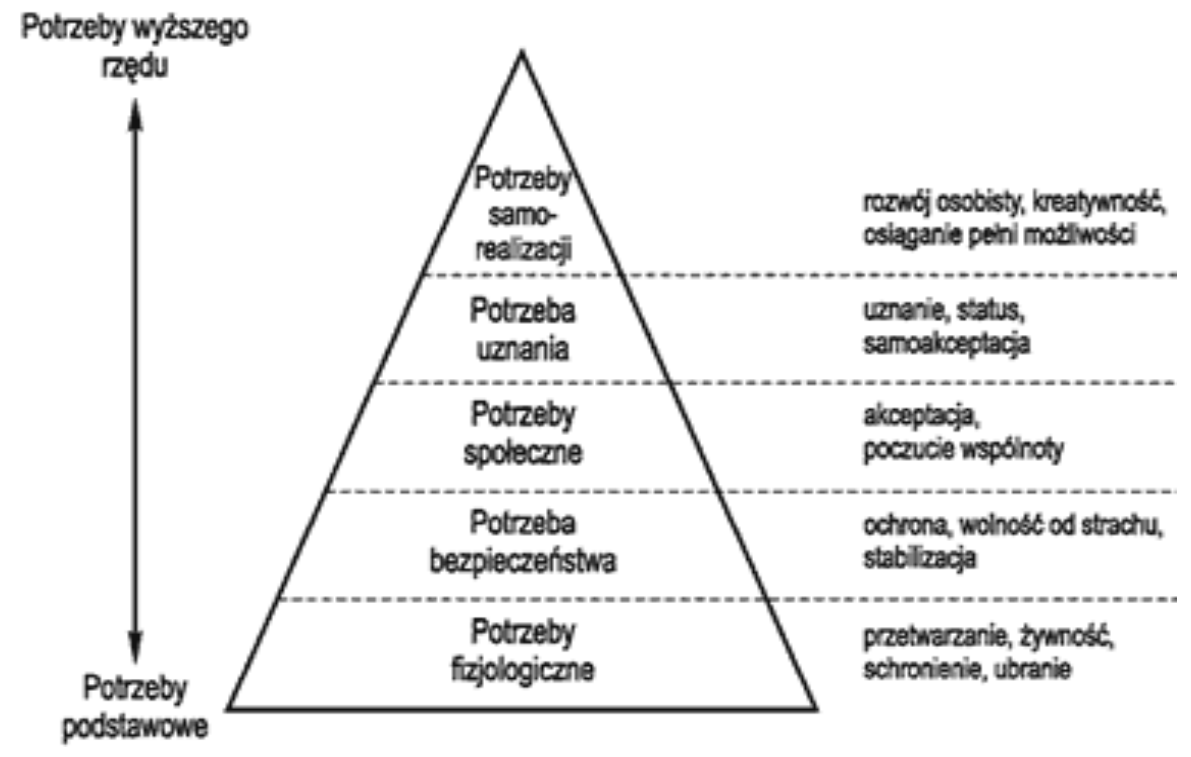

Źródło: Hierarchia Potrzeb Maslowa, [w:] Aneksy PWN

39 J. Altkorn, T. Kramer (red.), Leksykon marketingu, Warszawa 1998, s. 92.

40 Szerzej: A. Maslow, Motywacje i osobowość, Warszawa 2009, s. 62-76. 
Zatem rozpatrując potrzeby społeczne $w$ ujęciu globalnym (jako potrzeby i aspiracje ludności świata), można przyjąć za Grupą Lizbońską ich podział na dwie grupy. Do pierwszej zalicza się potrzeby związane z egzystencją na odpowiednim fizycznym, społeczno-ekonomicznym, politycznym i kulturalnym poziomie. Wymaga to zagwarantowania ${ }^{41:}$

- wyżywienia,

- energii,

- mieszkania,

- ochrony zdrowia,

- wykształcenia,

- wolności,

- bezpieczeństwa,

- pracy.

Drugą grupę tworzą potrzeby społeczne związane ze współistnieniem, realizowane za pomocą fizycznych i społecznych infrastruktur społeczno-gospodarczych, zasad mechanizmów zinstytucjonalizowanych form rządów i wielorakich form dialogu kulturowego. Z tego wynika, że ludność świata powinna mieć dostęp do ${ }^{42}$ :

- transportu,

- informacji,

- komunikacji,

- sztuki,

- demokracji,

- tożsamości kulturowej,

- sprawiedliwości,

- solidarności.

41 Encyklopedia marketingu. Definicje..., op. cit., s. 244.

42 Ibidem, s. 244. 
Anna Pasek - Potrzeby społeczne zwiqzane...

Natomiast w miarę rozwoju gospodarczego, wzrostu zamożności, wykształcenia i podnoszenia się poziomu kulturalnego coraz silniej odczuwane są takie potrzeby społeczne, jak ${ }^{43}$ :

- osiągnięć,

- niezależności,

- uznania przez innych,

- dominacji,

- bezpieczeństwa i zabezpieczenia,

- zabawy i wyłamywania się z rutyny, nowości,

- przynależności, opiekuńczości i troski o innych,

- współżycia i współdziałania.

Ogólnie rzec biorąc, w każdym kraju pomoc społeczna jest zorganizowana inaczej. Warto w tym miejscu podać przykład krajów uprzemysłowionych. Przeznaczają one znaczną część środków na potrzeby społeczne ${ }^{44}$. W tym celu niezbędne jest diagnozowanie potrzeb społecznych.

\subsection{Diagnozowanie potrzeb - podstawowe pojęcia}

Podstawowe pytania diagnozy w polityce społecznej dotyczą tego, jakie są potrzeby, jaka jest ich skala (jak dużej populacji dotyczą), poziom oraz sposoby ich zaspokajania ${ }^{45}$.

Istotne czynniki diagnozowania i zaspokajania potrzeb społecznych przedstawia Rysunek 2. Pokazuje on różne instrumenty diagnozowania i monitorowania problemów społecznych. Wnikliwa analiza takich czynników, jak: globalna polityka społeczna, kultura, tradycje, obyczaje narodów, systemy wartości i ich dynamika, ponadlokalne działania w celu zaspokojenia lokalnych potrzeb społecznych, sytuacja międzynarodowa, światowy rozwój gospodarczy, światowe zmiany ekologiczne, zmiany cywilizacyjne, struktury społeczne i demograficz-

\footnotetext{
43 Ibidem, s. 244.

${ }^{44}$ A. Giddens, Socjologia, wydanie nowe..., op. cit., s. 540.

${ }^{45}$ A. Rajkiewicz, J. Supińska, M. Księżpolski (red.) Polityka społeczna. Materiały do studiowania..., op. cit., s. 44.
} 
ne, wielkość budżetu, zasady redystrybucji, budżetów krajowych i ponadnarodowych ${ }^{46}$, pokazuje, że potrzeby społeczne stanowią kombinacje oddziaływania instytucji i infrastruktury ${ }^{47}$.

Rysunek 2. Istotne czynniki diagnozowania i zaspokajania potrzeb społecznych

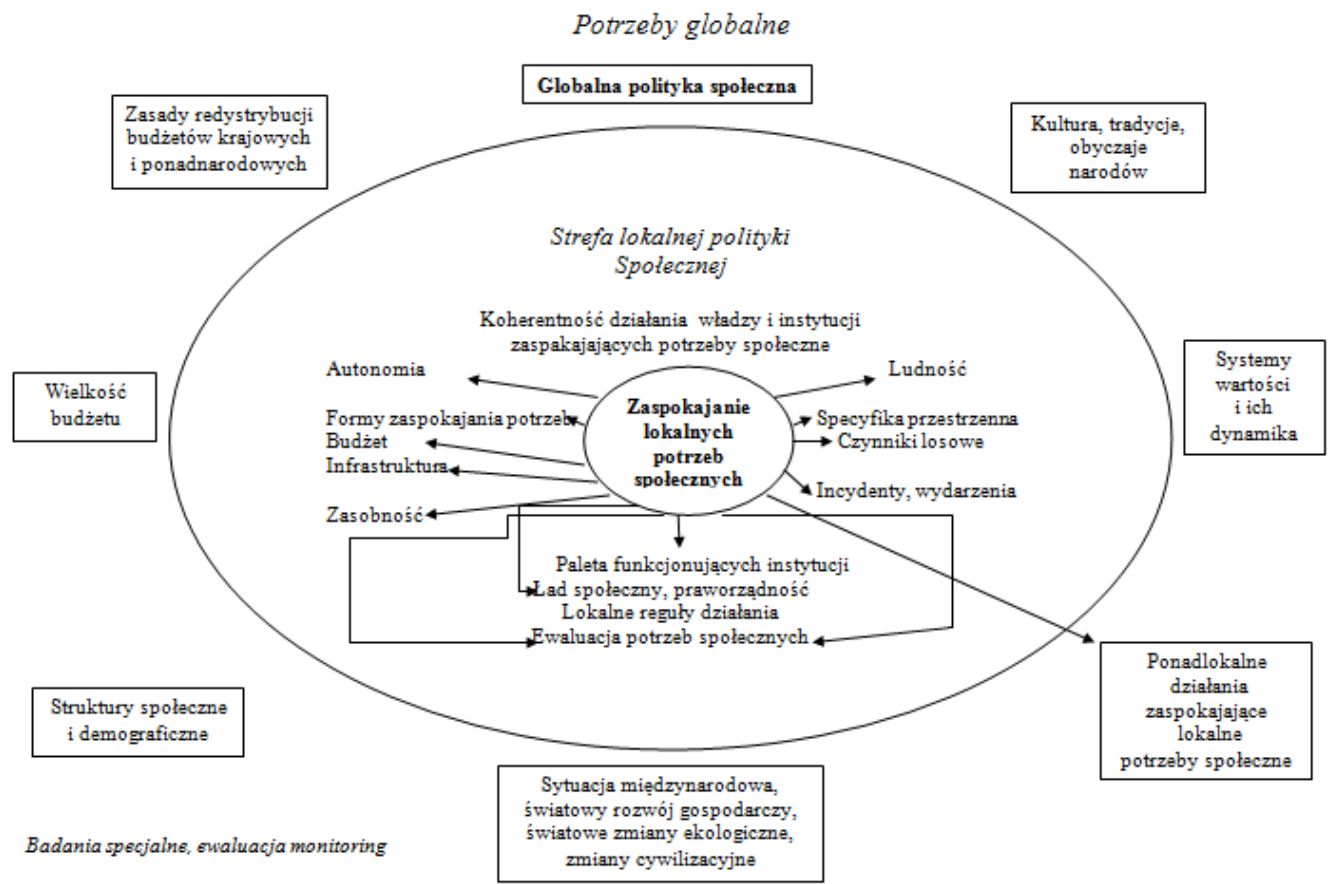

Źródło: A. Lisowski, Potrzeby społeczne i ich diagnozowanie..., op. cit., s. 69.

46 Por: J. Mair, J. Robinsons, K. Hockers (red.), Współczesna polityka społeczna, Przedsiębiorczość społeczna, Warszawa 2010, s. 55-56; B. Fiedor (red.), Ekonomia XXI wieku, Wrocław 2016, nr 3 (11), s. 9-10.

47 I. Grabowska, P. Śliwowski, Jakość życia mieszkańców a sprawność instytucjonalna jednostek samorzqdu terytorialnego - empiryczna weryfikacja koncepcji badawczej, [w:] E. Frątczak, T. Panek, T. Słaby (red.), Paradygmaty badawcze jakości życia w ekonomii zarzadzaniu i psychologii, Wrocław 2017, s. 83. 
Anna Pasek - Potrzeby społeczne zwiqzane...

Uzupełniając powyższy rysunek, można stwierdzić, że działalność w obrębie polityki społecznej prowadzona bywa w obrębie czterech podsystemów ${ }^{48}$ :

1) publiczny - realizowana jest przez agendy rządowe oraz samorządy lokalne;

2) rynkowy - świadczenia i usługi socjalne podlegają transakcjom kupna - sprzedaży;

3) nieformalny - obszar wsparcia i wymiany świadczeń oraz usług pomiędzy rodziną, przyjaciółmi, sąsiadami;

4) ochotniczy - oparty na idei samopomocy, wykorzystujący inicjatywy na najniższym piętrach organizacji społecznej lokalnej (organizacje obywatelskie, samopomocowe, zawodowe).

Jest rzeczą interesującą, że zdefiniowanie potrzeb społecznych przy użyciu przyjętego pojęcia potrzeb w ogóle wymaga rozstrzygnięcia arbitralnego. Można przyjąć, że potrzeby społeczne, to takie potrzeby, których zaspokajanie wymaga istnienia i działania instytucji społecznych na rzecz zamierzonych celów i o dających się przewidzieć z dostatecznym prawdopodobieństwem skutkach działania ${ }^{49}$. Przykładem mogą być problemy miast. Dlatego warto dodać, że podstawowe minimalne standardy zaspokajania potrzeb na poziomie lokalnym powinny być ustalane na poziomie centralnym z uwzględnieniem przy tym poziomu społeczno-ekonomicznego rozwoju kraju, aspiracji jego obywateli i międzynarodowych zobowiązań ${ }^{50}$. Takie podejście kreuje takie kierunki rozwoju prospołeczne i antyspołeczne ${ }^{51}$ :

- prawo do pracy,

- prawo do stopy życiowej zapewniające zdrowie i dobrobyt,

- prawo do płacy za wykonaną pracę,

- prawo do nauki,

\footnotetext{
48 K. Podolski, W. Turnowiecki, Polityka społeczna..., op. cit., s. 49.

${ }^{49}$ A. Lisowski, Potrzeby społeczne i ich diagnozowanie .... op. cit., s. 63.

50 Ibidem, s. 68.

${ }^{51}$ K. Podolski, W. Turnowiecki, Polityka społeczna ..., op. cit., s. 37-38.
} 
- prawo do uczestniczenia w życiu kulturalnym,

- prawo do wypoczynku i urlopu.

Chodzi mianowicie o to, że warunki wszechstronnego zagwarantowania praw człowieka trzeba rozpatrywać na tle rozwoju gospodarczego i socjalnego. Zapewnia to każdemu człowiekowi prawo do życia, wolności, bezpieczeństwa i równości wobec prawa w dziedzinach ekonomicznych oraz społecznych ${ }^{52}$. Przykładem mogą być potrzeby społeczne w miastach. W opinii mieszkańców są to:

a) komunikacja,

b) bezpieczeństwo,

c) potrzeby zdrowotne,

d) potrzeby mieszkaniowe.

Jak widać, środkiem realizacji celów polityki społecznej jest infrastruktura społeczna, czyli zespół urządzeń zaspokajających potrzeby socjalne, oświatowe i kulturalne ludności. Infrastruktura społeczna stanowi materialną podstawę zorganizowania państwa. Należą do niej m. in. zakłady pracy lub inne podmioty polityki społecznej, w tym także osoby prywatne. Przykładem może być też własność państwa lub samorządu terytorialnego ${ }^{53}$. Co za tym idzie, polityka społeczna w samorządzie jest silnie związana ze społecznością lokalną, z jej potrzebami ${ }^{54}$. Zatem rozwój lokalny oparty jest na inicjatywie i aktywnym uczestnictwie obywateli zamieszkujących konkretne terytorium i będących członkami społeczności lokalnej. Dokonuje się on na czterech płaszczyznach: gospodarczej, politycznej, społecznej i kulturalnej55.

W nauce o polityce społecznej przyjmuje się kilka podstawowych założeń dotyczących potrzeb ${ }^{56}$ :

52 Ibidem, s 32.

53 Ibidem, s. 44.

54 Ibidem, s. 48 - 51.

55 B. Jałowiecki, Rozwój lokalny, ..., op. cit., s. 344 - 345.

56 B. Kańtoch, B. Szatur-Jaworska, Diagnozowanie ludzkich potrzeb..., op. cit., s. $42-43$. 
Anna Pasek - Potrzeby społeczne zwiqzane...

- Społeczeństwo to źródło potrzeb w stopniu nie mniejszym niż jednostka.

- Potrzeby można uporządkować hierarchicznie ze względu na kryterium niezbędności ich zaspokojenia dla istnienia i rozwoju człowieka (tak jest wykorzystywana w polityce społecznej koncepcja A. H. Maslowa).

- Potrzeby jednostki ludzkiej zmieniają się w cyklu życia. Inna jest struktura potrzeb dziecka, a inna osoby dorosłej.

- Każda celowa działalność (polityka społeczna) wymaga określenia, co będzie uważane za osiągnięcie jej oczekiwanego efektu.

- W związku z różnorodnością potrzeb i zróżnicowanym poziomem aspiracji nie jest możliwe pełne usatysfakcjonowanie wszystkich członków społeczeństwa. Dlatego polityka społeczna posługuje się ogólnymi normami (w zależności od wieku).

- Potrzeby można badać empirycznie (obserwacja, rejestracja, analiza faktów społecznych). W związku z tym, że wielu potrzeb nie da się bezpośrednio zaobserwować, polityka społeczna korzysta z opracowanych przez statystyków wskaźników społecznych.

\subsection{Wyrównywanie szans}

Idea wyrównania szans, tj. tworzenia takiej sytuacji, w której ludzie będą mogli osiągnąć cele życiowe jest szczególnie ważna, gdy wiele osób korzysta z dobrodziejstw życia społecznego. Warto podkreślić, że kompleksowo zmienia się podejście do polityki społecznej. Zmienia się również hierarchia wartości potrzeb społecznych, kształtują się nowe, krańcowo różne grupy społeczne. Powstają ekstrema zaradności, sukcesu, bogactwa, a z drugiej strony - grupy osób nieza- 
radnych, sfrustrowanych, ubogich ${ }^{57}$. Głos zabrali w tej sprawie również D. Phillips, R. Bendix, S. M. Lipset czy M. Weber ${ }^{58}$.

Problemy polityki społecznej są rozpatrywane również w encyklikach papieskich. W encyklice Mater et Magistra z 1961 roku Jan XXIII podkreśla, że zasada dobra wspólnego oznacza ogół takich warunków życia społecznego, w których ludzie mogą pełniej i łatwiej osiągnąć własne doskonałości. Z kolei w encyklice Pacem in terris z 1964 roku podaje, że ochrona godności osoby wymaga przestrzegania praw, które jej przysługują. Dlatego do praw człowieka związanych z polityką społeczną zalicza prawo do życia i godnego jego poziomu, korzystania z wartości moralnych i kulturalnych, wolnego wyboru zawodu, zrzeszania się, emigracji i imigracji, udziału w życiu publicznym, ochrony praw obywatelskich ${ }^{59}$.

Z kolei Jan Paweł II w encyklice Centesimus annus z 1991 roku wypowiada się za budowaniem państwa pomocniczego ${ }^{60}$. Koncepcja ta polega na tym, że społeczność wyższego rzędu nie powinna ingerować w wewnętrzne sprawy społeczności niższego rzędu. Powinna ją wspierać w razie konieczności i pomóc w koordynacji jej działań z działaniami innych grup społecznych dla dobra wspólnego. Natomiast interwencja państwa powinna być ograniczona ${ }^{61}$. Encyklika ta stawia sprawę polityki społecznej w kategoriach moralnego prawa jednostki do domagania się od państwa warunków do rozwoju materialnego i duchowego. Warto podkreślić, że to nie jest sprawa dobrej

\footnotetext{
${ }^{57}$ Kondycja polityki społecznej jako dyscypliny badawczej, [w:] J. Supińska (red.) Polityka społeczna dziś i jutro. Opinie ekspertów, Warszawa 1999, s. 109.

58 D. Phillips, Rejection: a possible consequence of seeking help for mental disorders, „American Sociological Review” 1963, nr 28 [6], s. 963-972.; M. Weber, The development of caste, s. 28-36 [w:] R. Bendix, S. M. Lipset (red.), Class, status and power, Routledge and Kegan Paul, London 1967, [2nd edition], s. 31-32.

59 Jan XXIII, Encyklika Mater et Magistra, Paryż 1963, s. 47-121.; Jan XXIII, Encyklika Pacem in terris, Paryż 1964, s. 10.

60 Jan Paweł II, Encyklika Centesimus annus, 48, Watykan 1991, s. 38-40.

61 Por: Jan Paweł II, Centesimus annus, 48, Watykan 1991, s. 38-40.; Pius IX, Encyklika Quadragesimo anno, I, Rzym 1931, http://w2.vatican.va/content/pius-xi/en/ encyclicals/documents/hf_p-xi_enc_19310515_quadragesimo-anno.html [dostęp: 1702-2019].
} 
Anna Pasek - Potrzeby społeczne zwiq̨zane...

woli czy filantropii. Bowiem polityka społeczna powinna być współtworzona przez państwo i obywateli. Ważna jest też zasada pomocowości, która ułatwia budowę dobra wspólnego ${ }^{62}$.

Chodzi mianowicie o to, że społeczeństwo i państwo powinno gwarantować taki poziom zarobków, który wystarczyłby na utrzymanie pracownika i jego rodziny, a także pozwalał na gromadzenie pewnych oszczędności. Należy zagwarantować respektowanie ludzkiego czasu pracy i odpoczynku, a także prawa do wyrażania własnej osobowości w miejscu pracy. Państwo do realizacji tych celów powinno przyczyniać się pośrednio zgodnie z zasadami pomocniczości i bezpośrednio z zasadami solidaryzmu ${ }^{63}$.

Jak się okazuje, realizowane są tu różne modele polityki społecznej. Najbardziej rozbudowany jest model redystrybucyjny nastawiony na wyrównanie szans i dobrobytu społecznego. Dlatego warto przeanalizować potrzeby społeczne, które związane są z rozwojem społecznym.

\section{Analiza potrzeb społecznych związanych z rozwojem społecznym}

Głównym założeniem analizy jest zbadanie danego zjawiska poprzez podział na części. Przeprowadzając diagnozę potrzeb społecznych, należy przedstawić, jaki jest stan społeczeństwa i dlaczego tak jest. Zaś regularna diagnoza potrzeb społeczeństwa przyczynia się do rozwoju społeczeństwa. Jak się okazuje, w literaturze można spotkać różne sposoby (metody) diagnozowania potrzeb. Są to m. in. metody ilościowe (np. obserwacja społeczeństwa) czy czynniki diagnozowania potrzeb społecznych (zakres podmiotowy i przedmiotowy, czyli m. in. określenie terytorium badania) ${ }^{64}$.

62 Por: K. Podolski, W. Turnowiecki, Polityka społeczna..., op. cit., s. 22.; E. Karpowicz, Modele polityki społecznej. Kierunek zmian polityki społecznej w Polsce, Informacja BSiE, 2006, Nr 1249, s. 5.

${ }^{63}$ K. Podolski, W. Turnowiecki, Polityka społeczna..., op. cit., s. 26.

64 E. Babbie, Badania społeczne w praktyce, Warszawa 2003, s. 286. 
Ilustracją diagnozy społeczeństwa mogą być również dane pochodzące z badań sondażowych. Mowa tutaj o regularnych raportach. Metodę tę stosują autorzy Diagnozy społecznej, czyli cyklicznego badania Polaków. Innym przykładem mogą być prace badawcze zespołu CBOS (Centrum Badania Opinii Publicznej). Realizuje on badania jakościowe i ilościowe oraz projekty łączące obie te metody. Kolejnym potwierdzeniem są badania wykonane metodą audytoryjną. Doświadczenie to miało miejsce w 2007 roku na California State University Long Beach. Tematem było: „Zaspokajanie potrzeb tysięcy studentów”65.

Na potrzeby prowadzonej analizy przyjęto następujące założenie:

1) potrzeby są dynamiczne,

2) potrzeby mają swoją hierarchię (hierarchia potrzeb według Maslowa).

Zatem potrzeby są dynamiczne. Przeobrażeniom ulegają zwłaszcza procesy zaspokajania potrzeb i formy, w jakich się objawiają ${ }^{66}$. Współczesne gospodarki i społeczeństwo wymagają różnego rodzaju dóbr i usług, służących zaspokajaniu potrzeb jednostek i grup społecznych. Większość wytwarzanych dóbr i usług ma charakter dóbr rynkowych dostarczanych przez podmioty rynkowe. Oprócz nich bardzo ważną i rosnącą rolę odgrywają dobra publiczne oraz te dobra, które wytwarzane są przez firmy rynkowe, ale podlegają oddziaływaniu państwa, czyli tzw. dobra merytoryczne. Za dostarczenie dóbr publicznych odpowiedzialne jest państwo, ale w procesie tym coraz większą rolę odgrywają instytucje społeczeństwa obywatelskiego, a zwłaszcza organizacje pozarządowe ${ }^{67}$.

65 Por: J. Czapiński, T. Panek (red.), Diagnoza społeczna 2015. Warunki życia Polaków, Warszawa 2015; Zaufanie do polityków w lipcu. CBOS - Komunikat z badań nr 96/2018, [w:] https://www.cbos.pl/SPISKOM.POL/2018/K_096_18.PDF [dostęp: 13-11-2018]; P. Gleason, Meeting the Needs of Millennial Students 2007, [in:] California State University Long Beach

${ }_{66}$ A. Lisowski, Potrzeby społeczne i ich diagnozowanie..., op. cit., s. 73.

67 T. Michalak, J. Wilkin, Rynek, społeczeństwo obywatelskie, państwo a sytuacja grup marginalizowanych - ujęcie ekonomiczne (na przykładzie sytuacji w polskim rolnictwie), [w:] T. Kazimierczak, M. Rymsza (red.) W stronę aktywnej polityki społecznej, Warszawa 2003, s. 39. 
Anna Pasek - Potrzeby społeczne zwiq̨zane...

Dlatego też diagnoza problemów społecznych powinna obejmować różne potrzeby społeczne. Spostrzeżenie to posłuży zaplanowaniu działań związanych z usługami użyteczności publicznej. Zatem należy uwzględnić takie sfery, jak: demografia, rodzina, wyżywienie, edukacja, sytuacja materialna, integracja społeczna, zdrowie, bezpieczeństwo publiczne, mieszkalnictwo, kultura, sport i rekreacja, zatrudnienie, aktywność społeczna, środowisko naturalne ${ }^{68}$. Co za tym idzie rozwój społeczny można utożsamiać z potrzebami społecznymi z zakresu przyrody, kultury i organizacji.

Tabela 1 prezentuje zestawienie potrzeb wg piramidy Maslowa potrzeby społeczne kontra rozwój społeczny. Zestawienie to pokazuje, że te same potrzeby społeczne przejawiają się w rozwoju społecznym.

Nie ulega wątpliwości, że złożoność zjawisk społecznych powoduje, że na ogół wyniki jednego badania nie dają pełnych możliwości kompletnej diagnozy, zarówno przebiegu zjawiska, jak i opisu jego uwarunkowań oraz konsekwencji. Z tego względu ważnym kierunkiem doskonalenia statystyki społecznej jest integracja wiedzy o rozwoju społecznym ${ }^{69}$. Pomocne być może będzie m. in. zastosowanie innowacji. Bowiem innowacja może mieć czysto społeczny charakter ${ }^{70}$. Mowa tutaj w szczególności o innowacjach społecznych, czyli o zastosowaniu nowych, pożytecznych rozwiązań (odnoszących się do produktów, usług, modeli, rynków, proces itp.), które jednocześnie zaspokaja potrzeby społeczne (wprowadzają skuteczniejsze niż istniejące rozwiązanie) i prowadzą do nowych lub ulepszonych zdolności sprawczych społeczeństwa oraz lepszego wykorzystania posiadanych zasobów ${ }^{71}$.

68 T. Schimanek, Diagnozowanie potrzeb społecznych, Warszawa 2015, s. 9.

69 J. Witkowski, Statystyka - dokąd zmierzamy? ..., op. cit.

70 S. Kwiatkowski, Społeczeństwo innowacyjne, Warszawa 1990, s. 153.

${ }^{71}$ J. Caulier-Grice, A. Davies, R. Patrick, W. Norman, Defining Social Innovation. A deliverable of the project: "The theoretical, empirical and policy foundations for building social innovation in Europe" (TEPSIE), European Commission - 7th Framework Programme, European Commission, DG Research, Brussels 2012, https://cordis.europa.eu/project/rcn/101832/reporting/en [dostęp: 17-04-2019]. 
Tabela 1. Zestawienie potrzeb według piramidy Maslowa - potrzeby społeczne a rozwój społeczny

\begin{tabular}{|c|c|c|}
\hline Potrzeby & Potrzeby społeczne & Rozwój społeczny \\
\hline $\begin{array}{l}\text { Potrzeby } \\
\text { fizjologiczne }\end{array}$ & $\begin{array}{l}\text { Zakupy np. żywieniowe, } \\
\text { spożywanie posiłków w re- } \\
\text { stauracjach i barach szyb- } \\
\text { kiej obsługi, korzystanie } \\
\text { z toalety. }\end{array}$ & $\begin{array}{l}\text { Rozładowanie napięcia, zaspo- } \\
\text { kojenie popędu seksualnego, } \\
\text { podniesienie poziomu stymu- } \\
\text { lacji, umiejscowienie własne- } \\
\text { go wyglądu w rankingu } \\
\text { (allegro.pl, np. wielogodzinne } \\
\text { wyłączenie z rzeczywistości } \\
\text { poprzez praktykowanie czę- } \\
\text { stego kontaktu z przyrodą, np. } \\
\text { wakacje w Bieszczadach. }\end{array}$ \\
\hline $\begin{array}{l}\text { Potrzeby } \\
\text { bezpieczeństwa }\end{array}$ & $\begin{array}{l}\text { Poczucie bezpieczeństwa } \\
\text { socjalnego }\end{array}$ & $\begin{array}{l}\text { Brak anonimowości, można } \\
\text { wspomnieć tutaj o portalach } \\
\text { społecznościowych. Zaś anoni- } \\
\text { mowość - w przypadku pobie- } \\
\text { raniu zasiłków socjalnych } \\
\text { (wyrównanie szans). }\end{array}$ \\
\hline Potrzeby społeczne & Ochrona zdrowia & $\begin{array}{l}\text { Zaspokajana jest poprzez } \\
\text { potrzebę zdrowego stylu życia } \\
\text { (odżywianie, sport). }\end{array}$ \\
\hline Potrzeby uznania & $\begin{array}{l}\text { Uznanie i satysfakcja } \\
\text { z pracy }\end{array}$ & $\begin{array}{l}\text { Pozycjonowanie w rankingach } \\
\text { np. najlepszy pracownik. }\end{array}$ \\
\hline $\begin{array}{l}\text { Potrzeby } \\
\text { samorealizacji }\end{array}$ & $\begin{array}{l}\text { Działalność kulturalna, } \\
\text { działalność oświatowa, } \\
\text { Zaspokojenie potrzeby } \\
\text { estetycznej, poznawczej. }\end{array}$ & $\begin{array}{l}\text { Pozornie rozwój społeczny nie } \\
\text { zaspokaja potrzeb samoreali- } \\
\text { zacji, ale gdyby popatrzeć na } \\
\text { fakt, że dzięki niemu człowiek } \\
\text { ułatwia sobie życie, to można } \\
\text { przyjąć, że ta potrzeba jest } \\
\text { w ten sposób realizowana. }\end{array}$ \\
\hline
\end{tabular}

Źródło: opracowanie własne na podstawie A. Binsztok, T. Zuzański, Jak oczarować klientów w sklepie, czyli merchandasing z elementami psychologii zachowań konsumenckich, Gliwice 2013; B. Jałowiecki, Rozwój lokalny, Warszawa 1989, s. 348. 
Anna Pasek - Potrzeby społeczne zwiqzane...

Przykładem może być infrastruktura społeczna (m. in. ochrona zdrowia i pomocy społecznej) ${ }^{72}$.

Należałoby jeszcze postawić pytanie, czy można określić, które potrzeby społeczne i w jakim stopniu wpływają na rozwój społeczny. Przeprowadzona analiza pozwoliła na stworzenie modelu potrzeb, które przyczyniają się do rozwoju społecznego:

- potrzeba bezpieczeństwa (miejsce zamieszkania, dostępność dóbr i usług),

- potrzeby społeczne (aktywność mieszkańców, np. kluby spotkań),

- potrzeby uznania (przejmowanie wzorów),

- potrzeby własne, czyli potrzeby samorealizacji.

Co za tym idzie, przyrost produktywności w gospodarce możliwy jest m. in. dzięki zastosowaniu produktów sfery usługowej, które ucieleśniają wysoki wkład realizacji potrzeb społecznych. W tym celu należy przyjąć taki model działania, który ułatwi jego realizację, czyli wyznaczyć organ do identyfikacji potrzeb (np. Wydział Polityki Społecznej), zidentyfikować potrzeby, poszukać możliwych rozwiązań. Z kolei nowe rozwiązania ucieleśniają wysoki wkład kapitału intelektualnego oraz myśli technologicznej. Potwierdzają to dane Eurostatu z 2017 roku oraz Raporty OECD z 2018 roku73. Jest to już jednak temat na oddzielny artykuł.

\section{Podsumowanie}

Zmiany, które dokonują się w Polsce, zwłaszcza w zakresie warunków życia ludności i przemian społecznych, wymagają wszechstronnej i aktualnej wiedzy empirycznej. Monitorowanie tych zmian ułatwia podejmowanie decyzji sprzyjających dalszej przebudowie społe-

\footnotetext{
72 K. Podolski, W. Turnowiecki, Polityka społeczna..., op. cit., s. 44.

73 Por: High-tech statistics - economic data, Eurostat, January 2017; Science, Technology and Innovation News, OECD [dostęp: 22.03.2018]
} 
czeństwa polskiego ${ }^{74}$. Według standardów kształcenia w kolegiach pracowników służb społecznych jest między innymi przedmiot: ekonomiczne uwarunkowania potrzeb społecznych i ich zaspokajania. Ma on na celu skupić uwagę słuchaczy na bardzo ważnym aspekcie, jakim są potrzeby społeczne. Namysł nad tym może trafnie nazwać powstałe problemy i wygenerować odpowiednie rozwiązania. Ale czy one się sprawdzą? Jest to już temat na inny artykuł lub pracę badawczą.

\section{Bibliografia:}

Altkorn J., Kramer T. (red.) Leksykon marketingu, Polskie Wydawnictwo Ekonomiczne, Warszawa 1998.

Antonides G., van Raaij W. F., Zachowanie konsumenta. Podręcznik akademicki, Wyd. Naukowe PWN, Warszawa 2001.

Armstrong G., Kotler P., Marketing. Wprowadzenie, Wyd. Oficyna, Warszawa 2012.

Babbie E., Badania społeczne w praktyce, Wyd. Naukowe PWN, Warszawa 2003.

Bański J., Czapiewski K.Ł., Ekspertyza. Identyfikacja i ocena czynników sukcesu społeczno-gospodarczego na obszarach wiejskich. Instytut Geografii i Przestrzennego Zagospodarowania PAN, Warszawa 2008.

Binsztok A., Zuzański T., Jak oczarować klientów sklepie, czyli merchandising z elementami psychologii zachowań konsumenckich, Wyd. Helion, Gliwice 2013.

Caulier-Grice J., Davies A., Patrick R., W. Norman, Defining Social Innovation. A deliverable of the project: „The theoretical, empirical and policy foundations for building social innovation in Europe" (TEPSIE), European Commission - 7th Framework Programme, European Commission, DG Research, Brussels 2012, [w:] https://cordis.europa.eu/project/rcn/101832/repor ting/en [dostęp: 17-04-2019].

Cleveland H., Jacobs G., The Genetic Code for Social Development, „Human Choice", World Academy of Art \& Science, USA, 1999, s. 959-970.

${ }^{74}$ Ibidem. 
Anna Pasek - Potrzeby społeczne zwiqzane...

Czapiński J., Panek T. (red.), Diagnoza społeczna 2015. Warunki życia Polaków, Rada Monitoringu społecznego, Warszawa 2015.

Ekonomia od A do Z. Encyklopedia podręczna, S. Sztaba (red.), Wyd. Akademickie i Profesorskie, Warszawa 2007.

Encyklopedia marketingu. Definicje, Zasady, Agencja Wydawnicza Placet, Warszawa 1998

Fiedor B. (red.), Ekonomia XXI wieku, Wyd. Uniwersytetu Ekonomicznego we Wrocławiu, Wrocław 2016, nr 3(11).

Giddens A., Socjologia, wydanie nowe, Wyd. Naukowe PWN, Warszawa 2012.

Gleason P., Meeting the Needs of Millennial Students 2007, [w:] California State University Long Beach.

Grabowska I., Śliwowski P., Jakość życia mieszkańców a sprawność instytucjonalna jednostek samorzq̨du terytorialnego - empiryczna weryfikacja koncepcji badawczej, [w:] Frątczak E., Panek T., Słaby T. (red.), Paradygmaty badawcze jakości życia w ekonomii zarządzaniu i psychologii, Wyd. Uniwersytetu Ekonomicznego we Wrocławiu, Wrocław 2017.

Hierarchia Potrzeb Maslowa, [w:] Aneksy PWN

High-tech statistics - economic data, Eurostat, January 2017.

International Commission on Peace and Food, Uncommon Opportunities: An Agenda for Peace and Equitable Development, Zed Books, UK, 1994.

Jałowiecki B., Rozwój lokalny, Uniwersytet Warszawski, Warszawa 1989.

Jan Paweł II, Encyklika Centesimus annus, Libreria Editrice Vaticana, Watykan 1991.

Jan XXIII, Encyklika Mater et Magistra, Société d'Editions Internationales, Paryż 1963.

Jan XXIII, Encyklika Pacem in terris, Société d'Editions Internationales, Paryż 1964.

Kańtoch B., Szatur-Jaworska B., Diagnozowanie ludzkich potrzeb i ich zaspokajanie w polityce społecznej [w:] A. Rajkiewicz, J. Supińska, M. Księżpolski (red.), Polityka społeczna. Materiały do studiowania, Interart, Warszawa 1996.

Karpowicz E., Modele polityki społecznej. Kierunek zmian polityki społecznej $w$ Polsce, Informacja BSiE, 2006, Nr 1249,

Kelles-Krauz K., Historia i rewolucja, Wyd. Książka i Wiedza, Warszawa 1983.

Kondycja polityki społecznej jako dyscypliny badawczej [w:] J. Supińska (red.), Polityka społeczna dziś i jutro. Opinie ekspertów, Wyd. Instytut Spraw Publicznych, Warszawa 1999. 
Kwiatkowski S., Społeczeństwo innowacyjne, Polskie Wydawnictwo Naukowe PWN, Warszawa 1990.

Lisowski A., Potrzeby społeczne i ich diagnozowanie, [w:] A. Kurzynowski (red.), Polityka społeczna, Szkoła Główna Handlowa w Warszawie, Warszawa 2005, 52-74.

Mair J., Robinsons J., Hockers K. (red.) Współczesna polityka społeczna, Przedsiębiorczość społeczna, Wyd. Wyższej Szkoły Pedagogicznej TWP, Warszawa 2010.

Marciniak S. (red.) Makro- i mikroekonomia. Podstawowe problemy, Wyd. Naukowe PWN, Warszawa 2005.

Maslow A., Motywacje i osobowość, Wyd. Naukowe PWN, Warszawa 2009.

Michalak T., Wilkin J., Rynek, społeczeństwo obywatelskie, państwo a sytuacja grup zmarginalizowanych - ujęcie ekonomiczne (na przykładzie sytuacji w polskim rolnictwie) [w:] T. Kazimierczak, M. Rymsza, W stronę aktywnej polityki społecznej, Instytut spraw publicznych, Warszawa 2003.

Murray H. A., Explorations in personality, Oxford University Press, New York 1938.

Nasiłowski M., System Rynkowy. Podstawy mikro- i makroekonomii., Wyd. Key Text, Warszawa 2004.

Phillips D., Rejection: a possible consequence of seeking help for mental disorders, „American Sociological Review” 1963, nr 28 [6], s. 963-972.

Pius IX, Encyklika Quadragesimo anno, I, Rzym 1931, http://w2.vatican.va/ content/pius-xi/en/encyclicals/documents/hf_p-xi_enc_19310515_quad ragesimo-anno.html [dostęp: 17-02-2019].

Podolski K., Tarnowiecki W., Polityka społeczna, Wyd. Uniwersytetu Gdańskiego, Gdańsk 2001.

Rajkiewicz A., Supińska J., Księżpolski M. (red.) Polityka społeczna. Materiały do studiowania, Wyd. Interart, Warszawa 1996.

Rudnicki L., Zachowania konsumentów na rynku, Polskie Wydawnictwo Ekonomiczne, Warszawa 2012.

Schimanek T., Diagnozowanie potrzeb społecznych, FISE Fundacja Inicjatyw Społeczno-Ekonomicznych, Warszawa 2015.

Science, Technology and Innovation News, OECD, 22.03.2018

Šmid W., BOSS Leksykon, Wyd. DR LEX, Kraków 2014.

Szałkowski A., Rozwój pracowników. Przesłanki, cele instrumenty, Wyd. Poltex, Warszawa 2002.

Sztompka P., Socjologia zmian społecznych, Wyd. Znak, Kraków 2005. 
Anna Pasek - Potrzeby społeczne zwiqzane...

The well-being of nations. The role of human and social capital, Organization for Economic co- operation and development OECD, Paris 2001.

von Mises L., Ludzkie działanie. Traktat o ekonomii, Instytut Ludwiga von Misesa, Warszawa 2007.

Weber M., The development of caste, s. 28-36 [w:] R. Bendix, S. M. Lipset (red.), Class, status and power, Routledge and Kegan Paul, London 1967.

Wielka Encyklopedia PWN, t.24, Wyd. Naukowe PWN, Warszawa 2004.

Witkowski J., Statystyka - dokąd zmierzamy? Materiały pokonferencyjne: Statystyka społeczna - dokonania - szanse, perspektywy, Główny Urząd Statystyczny, 2008.

Zaufanie do polityków w lipcu. CBOS - Komunikat z badań nr 96/2018, https://www.cbos.pl/SPISKOM.POL/2018/K_096_18.PDF [dostęp: 1311-2018].

Zeliaś A., Tradycje i obecne zadania statystyki w Polsce, Wyd. Akademii Ekonomicznej w Krakowie, Kraków 2004. 